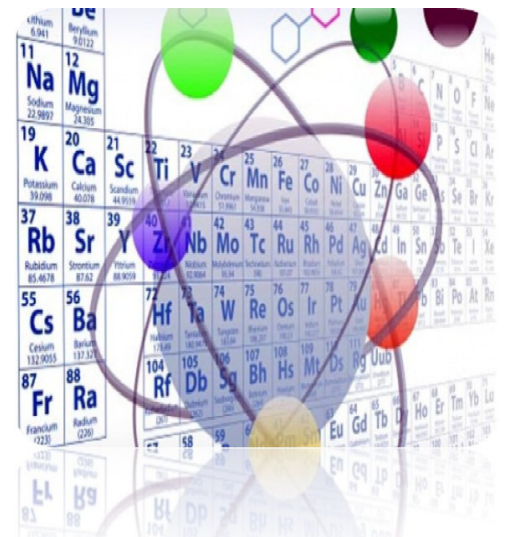

\title{
Analysis of Electrical Energy Contained in Vegetables
}

\author{
Annisa Tri Banoeari ${ }^{\mathrm{a} *}$, Tariza Humaira Tembusai ${ }^{\mathrm{a}}$, dan Riris Siahaan ${ }^{\mathrm{a}}$ \\ a Department of Chemistry, Faculty of Mathematics and Natural Sciences, Universitas Negeri Medan, Jl. Willem \\ Iskandar Pasar V Medan Estate, Medan 20221, Indonesia
}

*Email: annisatrbnoari@gmail.com

\begin{abstract}
This study aims to determine the source of electrical energy in potatoes and lime. The method used is based on the principle that the salt content in potatoes is a solution, where salt is the solute and water is the solvent, so the ions can move freely. The movement of the ions in the potato can conduct electricity. For the contained acid lime affects the hardness of the composite, which affects the matrix and filler bonds. oxalic acid, which is in lime juice, is a type of electrolyte solution. In a voltaic cell, the electrolyte solution can function to deliver ions from the anode to the cathode so that it can produce electrical energy. Electrical energy is energy that is very important in life. Electrical energy is a basic human need so that potatoes and lime can be used as an alternative source of electrical energy.
\end{abstract}

Keywords: electric energy, potatoes, lime, vegetables

\section{Pendahuluan}

Kentang (Solanum tuberosum L.) adalah tanaman dari suku Solanaceae yang memiliki umbi batang yang dapat dimakan dan disebut "kentang" pula. Umbi kentang sekarang telah menjadi salah satu makanan pokok penting di Eropa ${ }^{1}$. Kentang termasuk tanaman yang dapat tumbuh di daerah tropika dan subtropika ${ }^{2}$, Tanaman kentang toleran terhadap $\mathrm{pH}$ pada selang yang cukup luas, yaitu 4,5 sampai 8,0, tetapi untuk pertumbuhan yang baik dan ketersediaan unsur hara, $\mathrm{pH}$ yang baik adalah 5,0 sampai 6,5. Menurut Asandhi dan Gunadi (1989), tanaman kentang yang ditanam pada $\mathrm{pH}$ kurang dari 5,0 akan menghasilkan umbi yang bermutu jelek. Dalam hal gizi, kentang terkenal karena kandungan karbohidratnya (sekitar 26 gram dalam kentang medium). Bentuk dominan dari karbohidrat ini adalah pati. Sebagian kecil tapi signifikan pati ini adalah tahan terhadap

pencernaan oleh enzim dalam lambung dan usus kecil, sehingga mencapai usus besar dasarnya utuh.

Secara biokimia, karbohidrat adalah polihidroksil-aldehida atau polihidroksil-keton, atau senyawa yang menghasilkan senyawasenyawa ini bila dihidrolisis. Karbohidrat mengandung gugus fungsi karbonil (sebagai aldehida atau keton) dan banyak gugus hidroksil. Pada awalnya, istilah karbohidrat digunakan untuk golongan senyawa yang mempunyai rumus $\left(\mathrm{CH}_{2} \mathrm{O}\right) n$, yaitu senyawa-senyawa yang $\mathrm{n}$ atom karbonnya tampak terhidrasi oleh $\mathrm{n}$ molekul air. Namun demikian, terdapat pula karbohidrat yang tidak memiliki rumus demikian dan ada pula yang mengandung nitrogen, fosforus, atau sulfur. Jeruk nipis (Citrus aurantifolia) mempunyai kandungan asam yang dapat memengaruhi kekerasan komposit, disebabkan oleh menyerapnya air yang mengandung asam pada komposit yang memengaruhi ikatan matriks dan filler, ${ }^{3,4}$. 
Sel volta merupakan jenis sel elektrokimia yang dapat menghasilkan energy listrik dari reaksi redoks yang berlangsung spontan. Jeruk nipis merupakan sel volta, Karena kandungan kimia yang terdapat dalam jeruk nipis dapat berubah menjadi energy listrik. Hal ini ditentukan oleh anoda dan katoda dalam jeruk tersebut. Anoda yang berupa logam ditancapkan pada pangkal jeruk nipis. Sedangkan katoda yang berupa lempengan seng ditancapkan pada bagian bawah jeruk tersebut ${ }^{5,6}$. Listrik dapat mengalir karena adanya perpindahan electron bebas dari ion-ion dalam sebuah zat atau larutan. Larutan seperti senyawa asam, yaitu: asam sulfat, asam oksalat, asam format, dan asam sitrat merupakan jenis larutan elektrolit. Dalam sel volta, larutan elektrolit tersebut dapat berfungsi untuk menghantarkan ion dari anoda ke katoda sehingga dapat menghasilkan energy listrik. Larutan tersebut bisa di temukan pada sayur-sayuran atau buah seperti : kentang, jeruk nipis, tomat, timun, lemon, dan apel. Dapat disebabkan sayur dan buah-buahan dapat digunakan sebagai bahan alternatif sebagai pengganti sumber energy listrik.

\section{Metodologi Penelitian}

\subsection{Alat dan Bahan}

Bahan yang digunakan adalah 3 buah kentang dan 3 buah jeruk nipis. Alat yang digunakan adalah 3 buah uang koin, 3 buah paku, 1 buah lampu LED, 2 meter kabel, 8 buah penjepit buaya dan gunting.

\subsection{Prosedur Penelitian}

Siapkan 3 buah kentang, 3 buah jeruk nipis dan 1 buah lampu LED. Kemudian tancapkan 1 koin dan 1 paku ke setiap kentang dan jeruk nipis, lalu berikan jarak pada paku dan koin. Terlebih dahulu bagi menjadi 4 bagian kabel yang berukuran 2 meter tersebut, kemudian rakit kabel dengan penjepit buaya. 1 kabel terdapat 2 penjeit buaya. Kemudian hubungkan paku dengan koin menggunakan kabel yang sudah dirakit, penjepit buaya yang berwarna hitam hubungkan ke paku dan penjepit buaya yang berwarna merah hubungkan ke koin. Pada langkah ini harus sesuai tidak boleh terbalik. Dan lampu tersebut akan menyala, lakukan di ruangan yang gelap.

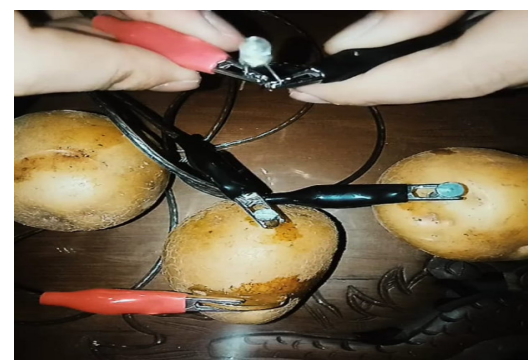

Gambar 1. Kentang dan Hubungkan Kabel dengan Koin dan Uang Logam

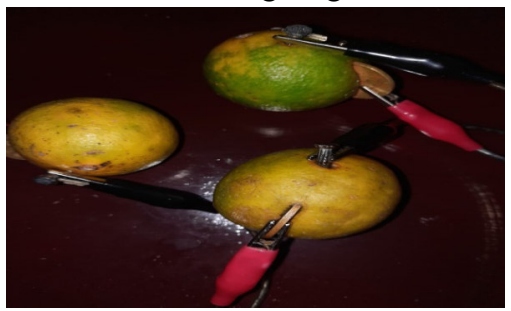

Gambar 2. Jeruk Nipis dan Hubungkan Kabel dengan Koin dan Uang Logam
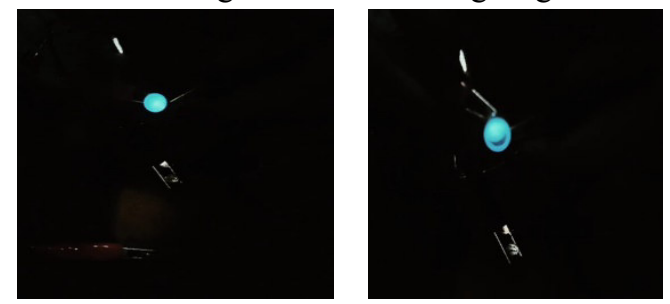

Gambar 3. Lampu LED Menyala pada Kentang dan Jeruk Nipis

\section{Hasil dan Diskusi}

\subsection{Analisis Energi Listrik pada Kentang}

Berdasarkan penelitian yang telah dilakukan pada kentang diperoleh energi listrik yang terdapat dalam kentang dapat menghasilkan lampu LED menyala. Adanya listrik pada kentang karena kentang mengandung zat-zat yang merupakan komponen penghasil listrik, diantaranya adalah : karbohidrat, kalium, protein, lemak, garam dapur $(\mathrm{NaCl})$, air $\left(\mathrm{H}_{2} \mathrm{O}\right)$, pati (amilum dan amilopektin), vitamin $\mathrm{B}$ dan $\mathrm{C}$, zat besi, riboflavin. Larutan garam $(\mathrm{NaCl})$ meruakan suatu larutan elektrolit yaitu larutan yang dapat menghantarkan arus listrik. Oleh sebab itu, kentang dapat menghasilkan listrik.

Selain adanya garam dan air, faktor lain yang menyebabkan kentang menghasilkan energi listrik yaitu karena adanya suatu reaksi ionisasi pada senyawa ion atau yang disebut dengan disosiasi. Senyawa ion tersusun atas ion positif (kation) dan ion negatif (anion). Senyawa ion akan terurai menjadi ion-ion (kation dan anion) ketika dilarutkan kedalam air, sebab ion-ion di dalam air 
akan bergerak bebas. Ion-ion yang bergerak bebas ialah ion yang hanya terdapat dalam larutan dan lelehan. Kandungan garam pada kentang merupakan suatu larutan, dimana garam merupakan zat terlarut dan air merupakan zat pelarut, sehingga ion-ionnya dapat bergerak dengan bebas. Gerakan ion-ion dalam kentang tersebut yang dapat menghantarkan listrik.

\subsection{Analisis Energi Listrik pada Jeruk Nipis}

Pada penelitian ini pun dilakukan pada jeruk nipis, diperoleh energi listik pada jeruk nipis yang menghasilkan lampu LED menyala pada saat kabel di hubungkan dengan logam, paku dan dijepit dengan penjepit buaya. Hal ini terjadi karena terdapat kandungan pada jeruk nipis yaitu larutan elektrolit dalam air asam jeruk nipis.

Jeruk nipis memiliki kemampuan yang mengahantarkan listrik yang baik. Dikarenakan jeruk nipis memiliki kandungan asam yang lebih banyak dibandingkan beberapa buah lain yang juga memiliki kandungan asam yang ditandai dengan nilai $\mathrm{pH}$ yang $\mathrm{kecil}^{7}$.

\section{Kesimpulan}

Berdasarkan hal tersebut diatas maka dalam penelitian ini dapat diambil kesimpulan bagian utama tanaman kentang yang menjadi bahan makanan adalah umbi. Karbohidrat merupakan persenyawaan kimia yang mengandung unsur karbon (C), Hidrogen (H), dan Oksigen (O). Untuk jeruk nipis asam yang terkandung memengaruhi kekerasan komposit, yang memengaruhi ikatan matriks dan filler. asam oksalat, yang ada pada cairan jeruk nipis merupakan jenis larutan elektrolit. Energi listrik merupakan energy yang sangat penting dalam kehidupan. Bahkan salah satu yang dapat kita temukan energi listrik sebagai kebutuhan pokok manusia sehingga kentang dan jeruk nipis bisa dijadikan bahan alternatif lain untuk sumber energi listrik.

\section{Aknowledgement}

Terimakasih kepada ibu Siti Rahmah dosen mata kuliah Kimia Non Logam, Program Studi Kimia Universitas Negeri Medan yang telah mendukung terlaksananya kegiatan penelitian ini.

\section{Referensi}

1. Pratama, T. "Pengaruh Penambahan Edible Coat Kitosan Sebagai Anti Jamur Pada Tepung Kentang”. Skripsi, Universitas Pendidikan
Indonesia, Bandung, 2013.

2. Ewing dan Keller. (1982). "Prospek dan Arah Pengembangan Agribisnis Kentang di Indonesia. Badan Penelitian dan Pengembangan Pertanian, Departemen Pertanian RI, Jakarta.

3. Sitanggang, P., Tambunan, E. \& Wuisan, J. (2015, Juni). "Uji Kekerasan Komposit Terhadap Rendaman Buah Jeruk Nipis (Citrus Aurantifolia)". Jurnal e-GIGI. 3(1). pp. 229234.

4. Riris, I.D., Juwitaningsih, T., Rosa, D., Damanik, M. \& Silalahi, A. (2020, July). "Study of Photocemicals, Toxicity, Antibacterial Activity of Ethyl Acetate Leaf Extract Extract (Paperomiapellucida L)". Indonesian Journal of Chemical Science and Technology. 3(2), pp. 74-80.

5. Mungkin, M. \& Ikhsan, T. (2016, Maret). "Filtrasi Jeruk Nipis Yang Ditambahkan $\mathrm{NaCl}$ + Na-EDTA sebagai Elektrolit Baterai dengan Charger Solar Cell”. Jurnal Saintika. 16(1), pp. $1-10$.

6. Addina, K.N. \& Lazulva. (2018, Jan.). "Potential of Bio-briquette of Pineapple Crown Waste (Ananas comosus (L.) merr)". Indonesian Journal of Chemical Science and Technology. 2(1), pp. 84-89.

7. Fitriyaningsih \& Partono. (2014). "Identifikasi Potensi Sari Buah Jeruk Menjadi Listrik Sebagai Sumber Belajar Fisika Materi Arus Listrik Siswa Smp Kelas IX". Jurnal Pendidikan Fisika. 2(2), pp. 11-21. 